\title{
Assessment of the effects of radiofrequency radiation on human colon epithelium cells
}

\author{
Tomruk A ${ }^{1}$, Terzi YK², Ozturk Guler $\mathrm{G}^{1}$ \\ Department of Biophysics, Gazi University Faculty of Medicine, Ankara, Turkey. arintomruk@gmail.com
}

\begin{abstract}
OBJECTIVES: The aim of the study was to investigate the possible effects of radiofrequency radiation (RFR) at different frequencies for different exposure durations on caspase-dependent apoptosis pathways in human colon adenocarcinoma (HT-29).

METHODS: HT-29 cells were exposed to $1800 \mathrm{MHz} ; 2100 \mathrm{MHz}$ and $2600 \mathrm{MHz}$ RFR for $3 \mathrm{~h}$ cont., $6 \mathrm{~h}$ int. and $6 \mathrm{~h}$ cont. Cell viability measurements were performed by Trypan Blue exclusion assay and the gene expressions of CASP8, CASP9, CASP3 and CASP12 were analyzed using qRT-PCR.

RESULTS: Exposure to $2100 \mathrm{MHz}$ RFR for all 3 durations of exposures was more effective for the ratio of the number of viable HT-29 cells w.r.t $1800 \mathrm{MHz}$ RFR and $2600 \mathrm{MHz}$ RFR exposures. After $2100 \mathrm{MHz}$ RFR exposure, caspase activation increased significantly (for $3 \mathrm{~h}$ cont. and $6 \mathrm{~h}$ int. exposures CASP8 and CASP9 levels; for 6 h cont. exposure CASP3 levels) ( $p<0.05$ ). Exposures to both $1800 \mathrm{MHz}$ and $2600 \mathrm{MHz}$ RFR for 3 different exposure durations did not change the activation of caspases we analyzed in this study $(p>0.05)$. CONCLUSION: Decreases in the cell viability of HT-29 cells for certain frequencies and also durations are consistent with significant increases in caspase activations. The results of caspase activation after $1800 \mathrm{MHz}$ or $2600 \mathrm{MHz}$ RFR exposures can be interpreted as the activation of different types of cell death pathway by caspase signaling cascades (Fig. 15, Ref. 56). Text in PDF www.elis.sk. KEY WORDS: radiofrequency field, HT-29, apoptosis, caspase activation, in vitro.
\end{abstract}

\section{Introduction}

All living organisms, including human beings, live in harmony with the natural electric (E) and magnetic (B) fields of the Earth because of the highly specialized and sensitive structure of their cells/ tissue against Electromagnetic (EM) fields. The sensitive and dynamic balance between living organisms and natural EM fields has been disrupted by the rapid development of artificial (man-made) EM technologies in the frequency ranges of 0 $\mathrm{Hz}$ to $300 \mathrm{GHz}$ [mobile phones, base stations, microwave ovens, radars, power lines, TV and radio transmitters, computers, electrical appliances etc.] (Panagopoulos, 2013). Intensive exposure to EM fields including Radiofrequency (RF) and Extremely Low Frequency (ELF) fields, in our everyday lives has been accepted as new types of environmental pollution (Redlarski et al, 2015). Meanwhile, the incidence and mortality rates of various cancer types have increased due to the influence of negative environmental conditions and as a consequence of abnormalities in genetic material (Ahlbom and Feychting, 2003).

${ }^{1}$ Department ofBiophysics, Gazi University Faculty of Medicine, Ankara,
Turkey, and ${ }^{2}$ Department of Medical Genetics, Baskent University Faculty
of Medicine, Ankara, Turkey

Address for correspondence: A. Tomruk, PhD, Department of Biophysics, Gazi University Faculty of Medicine, Emniyet Neighborhood Gazeteci Yazar Muammer Yaşar Bostancı Street, 06560 Ankara, Turkey.

Phone: +90.312.2024604, Fax: +90.312.2129023
The underlying mechanisms of biological responses associated with RF radiation exposure can be explained by two different approaches: thermal and non-thermal.

Interaction of RF fields with living systems has been characterized by its frequency, intensity, and exposure duration. However, interaction mechanisms are mainly based on the absorption of RF energy by biological matter. In the thermal mechanism, the RF electric field generates an oscillating current and the rapid transfer of the energy of this current into the molecular motion responsible for most of the heat capacity results in an increase in the local temperature. In contrast to thermal mechanism, non-thermal mechanism are based on the physical or biochemical changes in target cell, tissue, or organism but not related to temperature increase or tissue heating (Belyaev, 2005a, b). Moreover, Fröhlich (1968) has suggested that RF/MW range could create a resonance in the biomolecules. According to this suggestion, incident RF energy may be captured by a large group of oscillating dipoles and integrated into a single mode of coherent vibrational energy.

In the interaction mechanism of electromagnetic fields with biological system, it is noteworthy that not attenuated EM fields passed through cells can interact directly with the nuclear DNA and other structural molecules. With the induction of electric oscillations; the disturbance of cell membrane proteins, activation of enzyme cascades which transfer cell surface signals to the intracellular system, including cell nuclei and cell growth and division appear (IARC Monographs on the Evaluation of Carcinogenic 
Risks to Humans, IARC, 2013).

Cell cycle controls by tumor suppressor genes, DNA damage and repair mechanism, and apoptosis have played a critical role during the carcinogenesis process. However, induced resistance to programmed cell death is considered as a common characteristic of cancer cells. When an error occurs in the stages of chromosomal arrangement, DNA repair or DNA replication, cell cycle stops until all errors are repaired. Nevertheless, if there are irreversible errors or damages, apoptosis pathways are activated. And thus, the maintenance of balanced and healthy internal conditions (homeostatic balance) is ensured. Apoptosis, a vital biological process for several physiological and pathological events, enables the treatment of various diseases such as cancer, AIDS, autoimmune disorders etc. using biochemical methods and genetic components that either activate or inhibit. (Tomatır, 2003; Alberts et al, 1994). Therefore, to examine whether the impact of radiofrequency (RF) fields on cancer occurrence or treatment, the assessment of probable effects of EM fields on apoptosis mechanisms should be one of the most effective approaches.

It is important to understand and clarify that EM fields emitted from advanced technological devices that make our lives easier have contributed to an increase of the incidence of cancer as environmental risk factors and pollutants. Therefore, scientists have been working intensely on the probable link between EM fields-cancer interactions for over thirty-five years. According to literature, scientists and researchers began to develop an interest in two subjects: 1. there is a close relationship between EM fields and cancer incidence and 2. It is proposed that EM Fields can be used in cancer treatment as an adjuvant therapy.

International Agency for Research on Cancer [IARC-part of World Health Organization (WHO)] coordinated a feasibility study in 1998 and 1999, which concluded that an international study of the relationship between mobile phone use and brain tumor risk would be feasible and informative. The WHO/International Agency for Research on Cancer (IARC) has classified radiofrequency electromagnetic fields as possibly carcinogenic to humans (Group 2B), based on an increased risk for glioma, a malignant type of brain cancer, associated with wireless phone use (THE WHO/ IARC PRESS RELEASE NO 208, 31 May 2011).

In the present study, the probable effects of wireless technologies at different frequencies [GSM-like signal (1800 MHz), 3G UMTS mobile communications (2100 MHz) and 4G Long Term Evolution (LTE) (2600 MHz)] on caspases-dependent apoptosis mechanisms in human colorectal adenocarcinoma cells were investigated for different exposure durations [ $3 \mathrm{~h}$ continuous, $6 \mathrm{~h}$ intermittent and $6 \mathrm{~h}$ continuous].

\section{Materials and methods}

\section{Cell culture}

Human colorectal adenocarcinoma cell line was obtained from the American Type Culture Collection (ATCC; USA). HT-29 (ATCC®HTB-38) was cultured in Dulbecco's modified eagle's medium (Biochrom-Merck GmbH, Germany) supplemented with $10 \%$ Foetal bovine Serum (FBS, F4135, USA origin Heat Inacti- vated, sterile-filtered, suitable for cell culture, Sigma-Aldrich-Mer$\mathrm{ck}, \mathrm{GmbH}$, Germany) and $1 \%$ penicillin/streptomycin (Solution stabilized with 10,000 units penicillin and $10 \mathrm{mg}$ streptomycin/ $\mathrm{mL}$, sterile- filtered suitable for cell culture, Sigma-Aldrich-Merck, $\mathrm{GmbH}$, Germany). Cells were grown to confluence in T75 flasks (Nest Biotechnology, USA) in a $37^{\circ} \mathrm{C}$ incubator (Nüve, EN120, Ankara, Turkey) at $5 \% \mathrm{CO} 2$. HT-29 cells were passaged after growing to $90 \%$ confluency and replaced equally (1x106cells/ $\mathrm{ml}$ ) into the sterile $35 \mathrm{~cm}^{2}$ Petri dishes for RF radiation exposure.

\section{$R F$ radiation exposure system}

The RF exposure system mainly consists of

- a plexiglass box $(32 \times 52 \times 75 \mathrm{~cm})$ covered by RF absorber foam (1-17 GHz, 5 mm, 3500 Microwave absorber foam, Holland Shielding Systems BV, The Netherlands) for the elimination of both external and internal reflections,

- a vector signal generator (Rohde \&Schwarz SMBV 100A, 9 $\mathrm{kHz}-3.2 \mathrm{GHz}$, München, Germany) for the generation of digitally modulated RF signals.

- a horn antenna (Schwarzbeck, Doppelsteg Breitband Horn antenna BBHA 9120 L3F, 0.5-2.8 GHz, Schönau, Germany) for the emissions of the RF signals generated by the vector signal generator.

- a digital microscope hot plate unit (Nikon, Thermo Plate, Japan) for keeping the stability of cells' temperatures.

The output power and the frequency were controlled by a spectrum analyzer (Rohde \& Schwarz, FSH 18, 10 MHz-18 GHz, München, Germany) integrated to the signal generator. The distance between the horn antenna and the cell culture plates was $20 \mathrm{~cm}$ to provide far field conditions. Environmental Radiofrequency Electric (E) and Magnetic (B) Fields were measured by using NARDA EMR-300 device and its E field probe $(100 \mathrm{kHz}-3$ $\mathrm{GHz})$ and NARDA EMF 300 and its B field probe $(5 \mathrm{~Hz}-32 \mathrm{kHz})$ (Narda, Pfullingen, Germany) (Fig. 1).

Human colorectal cells were exposed to $1800 \mathrm{MHz}, 2100$ $\mathrm{MHz}$ and $2600 \mathrm{MHz} \mathrm{RF}$ radiations with a SAR of $1.6 \mathrm{~W} / \mathrm{kg}$ for: i. 3 hours continuously, ii. 6 hours intermittently [ 3 hours RF exposure setup on/1 hour RF exposure setup off (At this time, cells were kept in a $5 \% \mathrm{CO}_{2}$ incubator) $/ 3$ hours $\mathrm{RF}$ exposure setup on], iii. 6 hours continuously in order to investigate the probable effects of RF radiation on caspase-dependent programmed cell death. The incident power generated by the signal generator was $1 \mathrm{~W}$, and the measured output E field values were $31.20 \pm 0.95$ $\mathrm{V} / \mathrm{m}$ for $1800 \mathrm{MHz}, 31.56 \pm 0.27 \mathrm{~V} / \mathrm{m}$ for $2100 \mathrm{MHz}$ and 31.43 $\pm 1.15 \mathrm{~V} / \mathrm{m}$ for $2600 \mathrm{MHz}$. The direction of the RF propagation was perpendicular to the diameters of the wells.

Before the analysis of gene expression, the percentage of cell viability between the control, sham and RF radiation exposure groups were determined by trypan blue staining assay. These experiments were repeated at least three times.

\section{Semi-quantitative RT-PCR}

Total RNA was extracted from HT-29 cell line with Trizol reagent according to the manufacturer's protocol (Roche Diagnostics $\mathrm{GmbH}$, Mannheim, Germany). The concentration of the extract- 


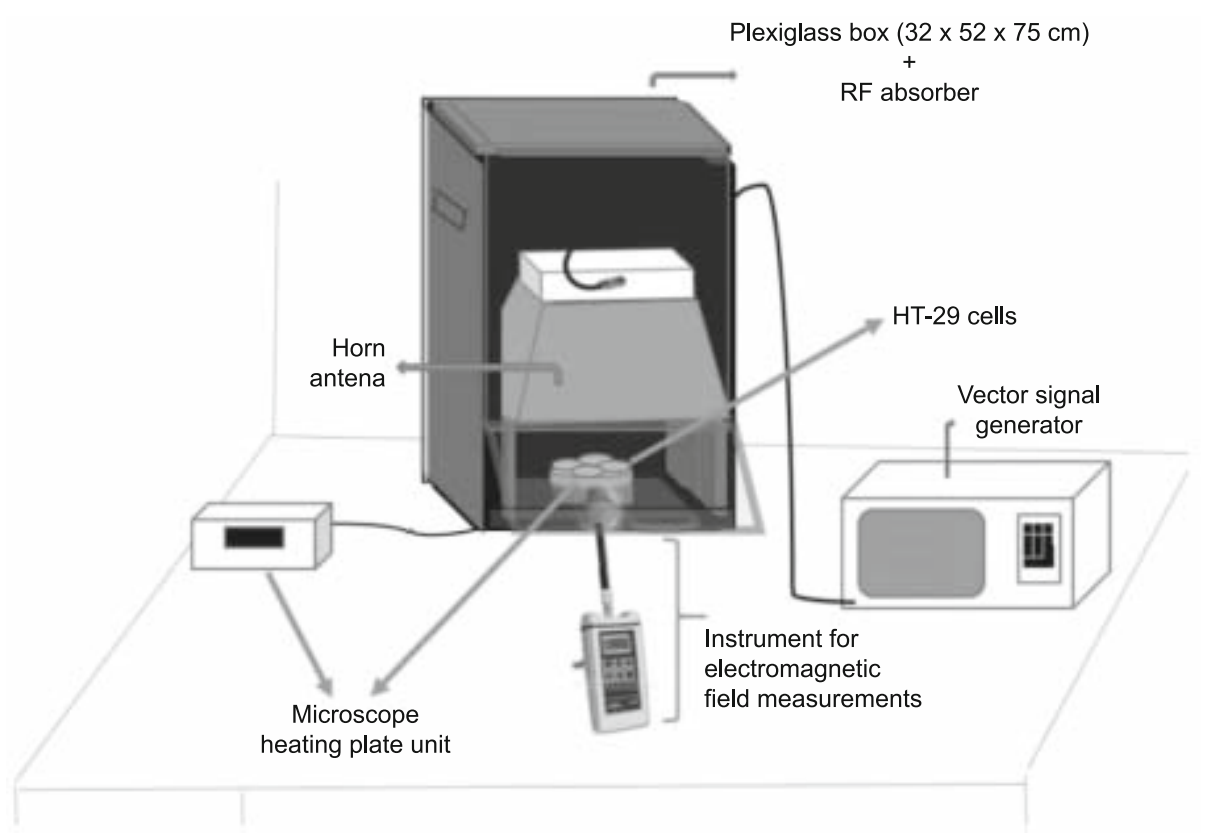

Fig. 1. RF Exposure Setup.

ed total RNA was assessed by using NanoDrop 2000 Spectrophotometer (Thermo Scientific, Wilmington, DE). Its purity and integrity were determined by ratio of absorbance at $240 / 260$ and 280/260 nanometers. The measured RNA purities of whole samples are in the range of 1.8-2.0. One microgram of total RNA was reverse transcribed using Transcriptor High Fidelity cDNA Synthesis Kit (Roche Diagnostics GmbH, Mannheim, Germany). PCR reactions were in a $20 \mu 1$ total volume according to manufacturer's protocol using Template-Primer Mix, Master Mix, $5 \mu 1$ cDNA and the primers for a) CASP8 5' TTTCTGCCTACAGGGTCATGC 3' (Forward) and 5'TGTCCAACTTTCCTTCTCCCA3'(Rever se) b) CASP9 5'CTGTCTACGGCACAGATGGAT3'(Forward) and 5'GGGACTCGTCTTCAGGGGAA3'(Reverse) c) CASP3 5'CATGGAAGCGAATCAATGGACT3'(Forward) and 5'CTGTACCAGACCGAGATGTCA 3' (Reverse) d) CASP12 5'AA CAACCGTAACTGCCAGAGT3'(Forward) and 5' CTGCACCGGCTTTTCCACT3' (Reverse) e) Housekeeping control gene 5'GGCACCCAGCACAATGAAG3'(Forward) and 5'CCGATCCACACGGAGTACTTG 3' (Reverse). PCR reactions were briefly as $95{ }^{\circ} \mathrm{C}$ for $5 \mathrm{~min}$ followed by 40 cycles at $95^{\circ} \mathrm{C}$ for $10 \mathrm{sec}, 50$ ${ }^{\circ} \mathrm{C}$ for $20 \mathrm{sec}$ and $72{ }^{\circ} \mathrm{C}$ for $30 \mathrm{sec}, 1 \mathrm{cycle}$ of $72^{\circ} \mathrm{C}$ for $7 \mathrm{~min}$ and extension at $4{ }^{\circ} \mathrm{C}$. The relative expression level of the genes was calculated using the 2- $\Delta \Delta \mathrm{Ct}$ method (Livak and Schmittgen, 2001).

\section{Statistical analysis}

Nonparametric Kruskal-Wallis test was used for analysis of difference between groups. Significant differences between groups were determined using Mann-Whitney U test. A p value less than 0.05 was considered as statistically significant. All statistical analyses and tests were performed with the SPSS statistical package (SPSS 20.0 for Windows, Chicago, IL, USA).

\section{Results}

The results of comparing cell viability are shown in Figure $2 \mathrm{a}, \mathrm{b}, \mathrm{c}$.

\section{$1800 \mathrm{MHz}$ RF radiation exposure}

\section{Cell viability}

We observed the percentage rates of cell viabilities of HT-29 cells exposed to $1800 \mathrm{MHz}$ GSM-like RF radiation for three hours (continuous) and six hours (intermittent) [3 hours RF exposure setup on/1hour RF exposure setup off/3hours RF exposure setup on] and they did not change significantly with respect to their negative control and sham groups $(p>0.05)$. However, a significant decrement in six hours (continuous) exposure groups was determined $(\mathrm{p}<0.05)$.

\section{Genetic analysis}

We analyzed the gene expression levels of CASP8, CASP9, CASP3 and CASP12, they did not change significantly with the exposure to $1800 \mathrm{MHz}$ GSM-like RF radiation for all three exposure durations compared to their negative control and sham groups $(\mathrm{p}>0.05)$ (Figs 3-6).

\section{$2100 \mathrm{MHz}$ RF radiation exposure}

\section{Cell viability}

Significantly decrements were observed in the percentage rates of cell viabilities of HT-29 cells exposed to $2100 \mathrm{MHz}$ GSM-like signals for all three exposure durations compared to their negative controls and sham groups $(\mathrm{p}<0.05)$. 


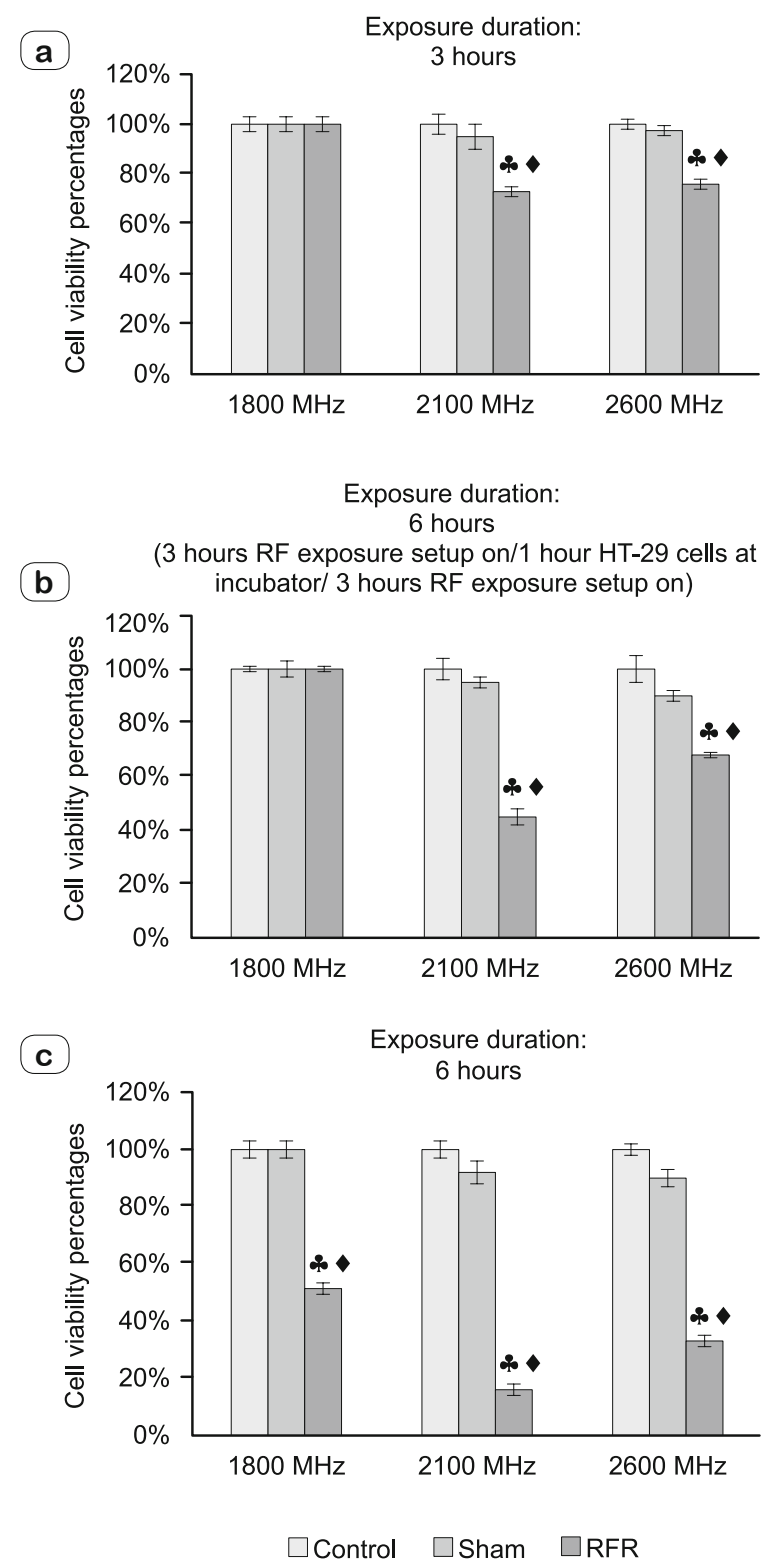

Fig. 2. The cell viability percentages of HT-29 cells exposed to 1800 $\mathrm{MHz}, 2100 \mathrm{MHz}$ and $2600 \mathrm{MHz}$ RF radiation for 3 hours continuous (a), 6 hours intermittent (HT-29 cells were exposed to RF radiation for 3 hours continuous/ 1 hour HT-29 cells were held at incubator / HT-29 cells were exposed to RF radiation for 3 hours continuous) (b) and 6 hours continuous (c). $\bullet ; \bullet:$ RFR exposure Group vs Control and Sham Groups respectively $(p<0.05)$

\section{Genetic analysis}

We found significant increases in the gene expression levels of CASP8 and CASP9 of HT-29 cells exposed to $2100 \mathrm{MHz}$ GSMlike signals for three hours (continuous) and six hours (intermittent) [ 3 hours on/1 hour off/ 3 hours on] with respect to their negative control and sham groups $(\mathrm{p}<0.05)$.

The expression levels of CASP 3 of HT-29 cells exposed to $2100 \mathrm{MHz}$ RF radiation increased significantly only for six hours

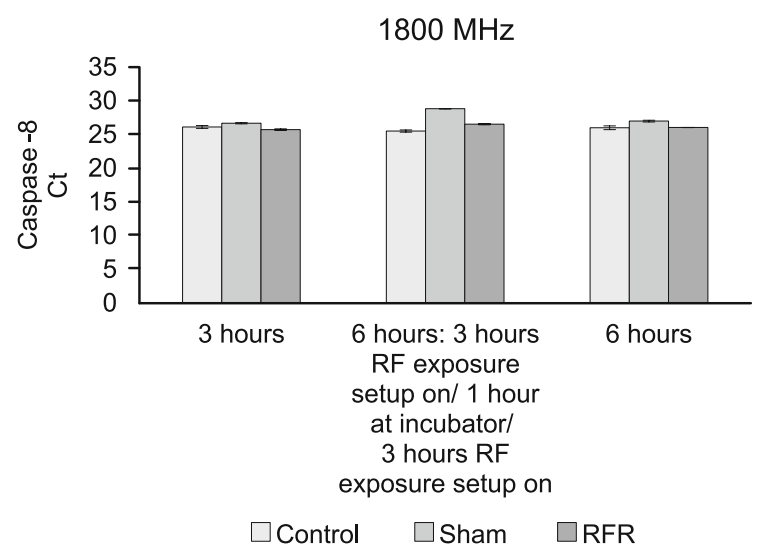

Fig. 3. The gene expression levels of CASP8 in HT-29 cells exposed to $1800 \mathrm{MHz}$ RF radiation for 3 hours continuous, 6 hours intermittent (HT-29 cells were exposed to RF radiation for 3 hours continuous/ 1 hour HT-29 cells were held at incubator / HT-29 cells were exposed to RF radiation for 3 hours continuous) and 6 hours continuous.

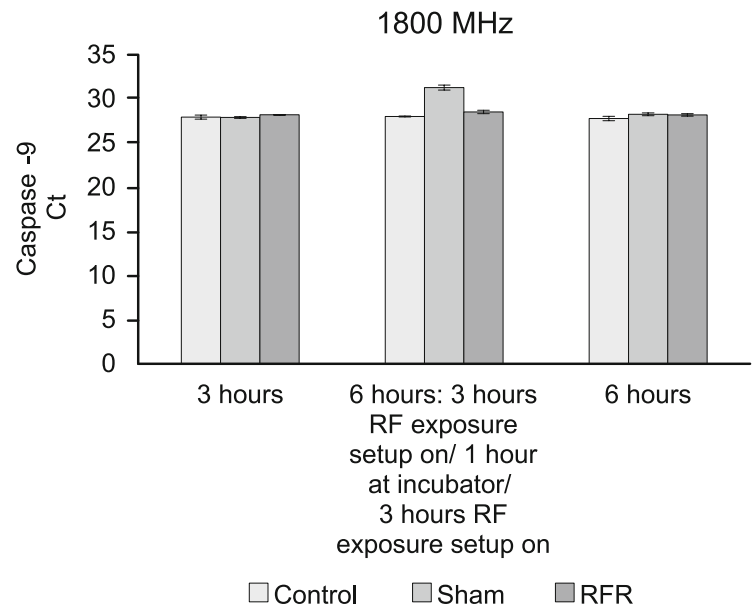

Fig. 4. The gene expression levels of CASP9 in HT-29 cells exposed to $1800 \mathrm{MHz}$ RF radiation for 3 hours continuous, 6 hours intermittent (HT-29 cells were exposed to RF radiation for 3 hours continuous/ 1 hour HT-29 cells were held at incubator / HT-29 cells were exposed to RF radiation for 3 hours continuous) and 6 hours continuous.

(intermittent) [3 hours on/ 1 hour off/ 3 hours on] compared to their negative control and sham groups $(\mathrm{p}<0.05)$.

In this study, we did not find any differences in the gene expression levels of CASP8, CASP9, CASP3 and CASP12 of HT29 cells exposed to $2100 \mathrm{MHz}$ RF radiation for six hours (continuous) with respect to their negative control and sham groups $(\mathrm{p}>0.05)$.

The gene expression level of CASP12 did not change under exposure to $2100 \mathrm{MHz}$ RF radiation for all three exposure durations compared to their negative control and sham groups $(\mathrm{p}>$ 0.05) (Figs 7-10). 


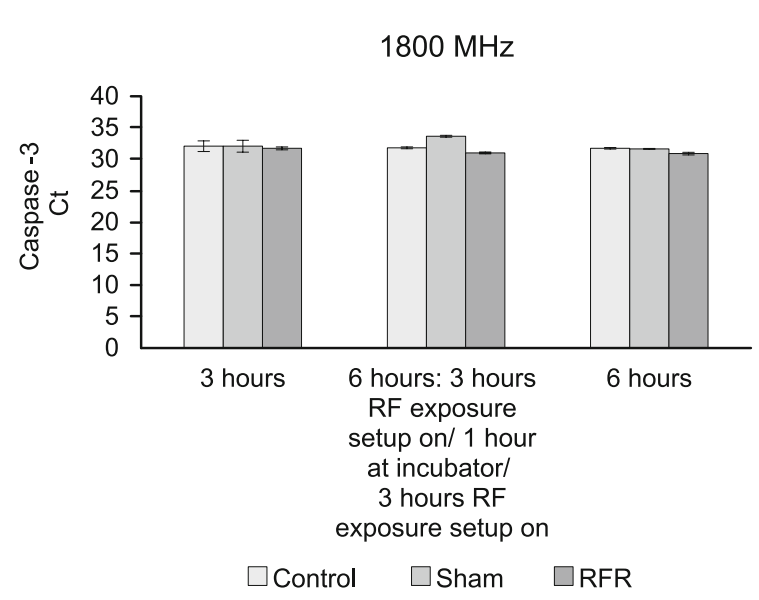

Fig. 5. The gene expression levels of CASP 3 in HT-29 cells exposed to $1800 \mathrm{MHz}$ RF radiation for 3 hours continuous, 6 hours intermittent (HT-29 cells were exposed to RF radiation for 3 hours continuous/ 1 hour HT-29 cells were held at incubator / HT-29 cells were exposed to RF radiation for 3 hours continuous) and 6 hours continuous.

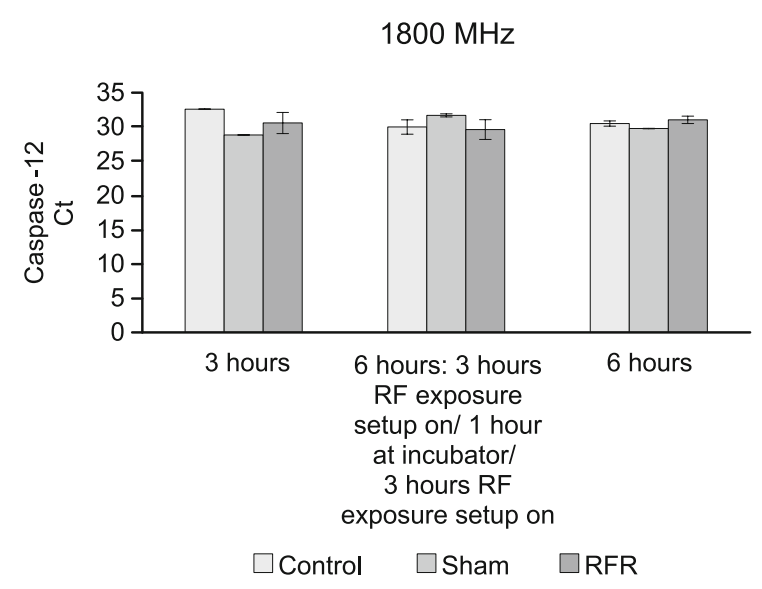

Fig. 6. The gene expression levels of CASP12 in HT-29 cells exposed to $1800 \mathrm{MHz}$ RF radiation for 3 hours continuous, 6 hours intermittent (HT-29 cells were exposed to RF radiation for 3 hours continuous/ 1 hour HT-29 cells were held at incubator / HT-29 cells were exposed to RF radiation for 3 hours continuous) and 6 hours continuous.

\section{$2600 \mathrm{MHz}$ RF radiation exposure}

\section{Cell viability}

Significant decreases were found in the percentage rates of cell viabilities of HT-29 cells exposed to $2600 \mathrm{MHz}$ GSM-like signals for all three exposure durations compared to their negative controls and sham groups $(\mathrm{p}<0.05)$.

\section{Genetic analysis}

The gene expression levels of CASP8, CASP9, CASP3 and CASP12 did not change under exposure to $2600 \mathrm{MHz}$ RF radia-
$2100 \mathrm{MHz}$

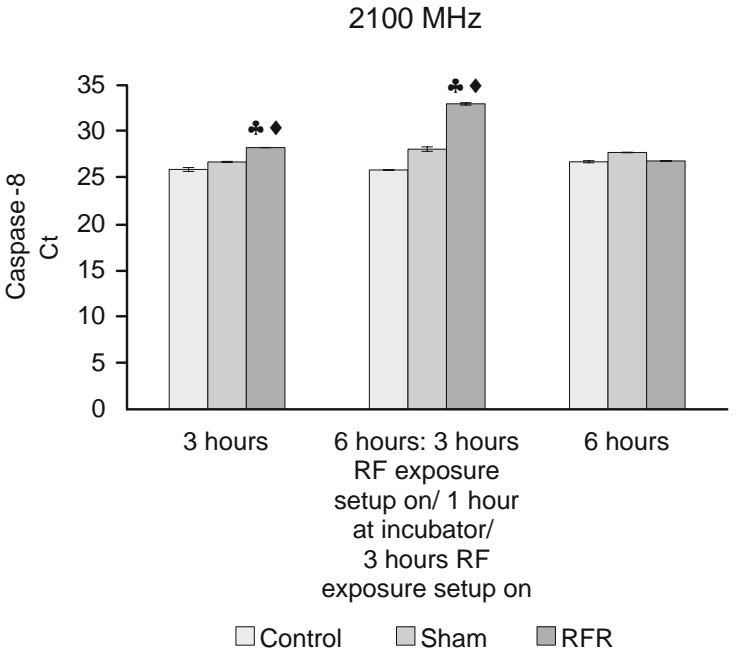

Fig. 7. The gene expression levels of CASP8 in HT-29 cells exposed to $2100 \mathrm{MHz}$ RF radiation for 3 hours continuous, 6 hours intermittent (HT-29 cells were exposed to RF radiation for 3 hours continuous/ 1 hour HT-29 cells were held at incubator / HT-29 cells were exposed to RF radiation for 3 hours continuous) and 6 hours continuous. $\star ; \bullet:$ RFR exposure Group vs Control and Sham Groups respectively $(\mathrm{p}<0.05)$

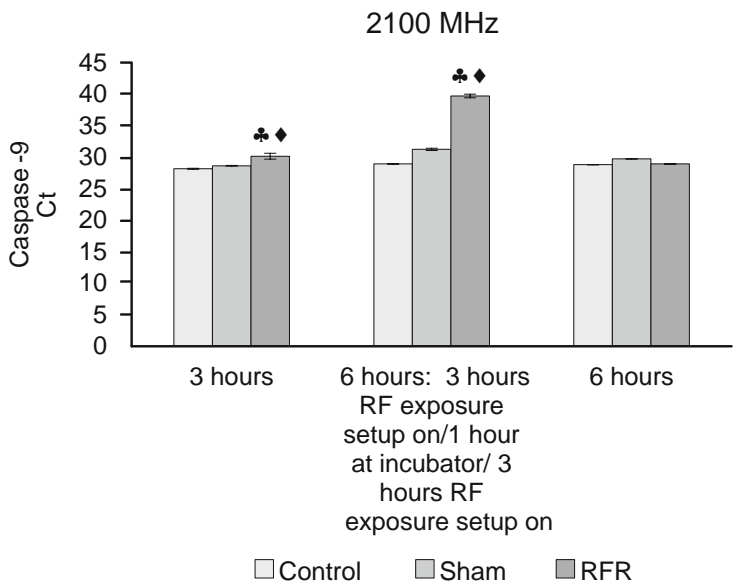

Fig. 8. The gene expression levels of CASP9 in HT-29 cells exposed to $2100 \mathrm{MHz}$ RF radiation for 3 hours continuous, 6 hours intermittent (HT-29 cells were exposed to RF radiation for 3 hours continuous/ 1 hour HT-29 cells were held at incubator / HT-29 cells were exposed to RF radiation for 3 hours continuous) and 6 hours continuous. ^; : RFR exposure Group vs Control and Sham Groups respectively $(\mathbf{p}<\mathbf{0 . 0 5})$

tion for all three exposure durations compared to their negative control and sham groups ( $\mathrm{p}>0.05)$ (Figs 11-14).

\section{Discussion}

In this study, we intended to investigate the probable impacts of RFR exposure at different frequencies [2nd generation (1800 MHz GSM-like RF signal), 3rd generation (2100 MHz UMTSlike RF field) and New Mobile Phone 4th generation (2600 MHz 


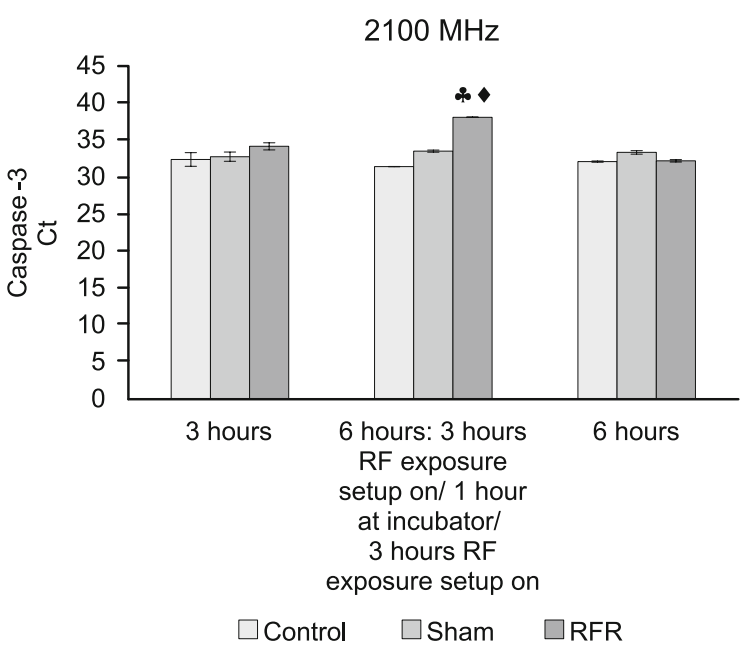

Fig. 9. The gene expression levels of CASP3 in HT-29 cells exposed to $2100 \mathrm{MHz}$ RF radiation for 3 hours continuous, 6 hours intermittent (HT-29 cells were exposed to RF radiation for 3 hours continuous/ 1 hour HT-29 cells were held at incubator / HT-29 cells were exposed to RF radiation for 3 hours continuous) and 6 hours continuous. \&; : : RFR exposure Group vs Control and Sham Groups respectively $(\mathbf{p}<0.05)$

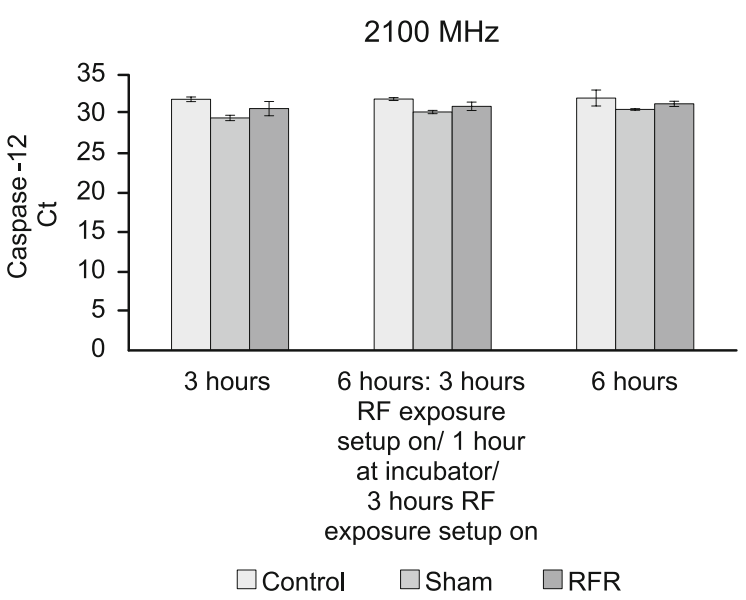

Fig. 10.The gene expression levels of CASP12 in HT-29 cells exposed to $2100 \mathrm{MHz}$ RF radiation for 3 hours continuous, 6 hours intermittent (HT-29 cells were exposed to RF radiation for 3 hours continuous/ 1 hour HT-29 cells were held at incubator / HT-29 cells were exposed to RF radiation for 3 hours continuous) and 6 hours continuous.

LTE Signal Repeater)] for different exposure durations (3 hours continuous, 6 hours intermittent, 6 hours continuous) on caspasedependent cell death in human colorectal adenocarcinoma cell lines. Radiofrequency radiation has been suggested as a stress inducer that can activate and/ or maintain various biochemical and physiological responses (French et al, 2001). And thus, we applied different RF signals as the probable stress factor to human colon cancer cells and analyzed gene expression levels of caspases : caspases involved in the extrinsic pathway (CASP8, CASP3), in the

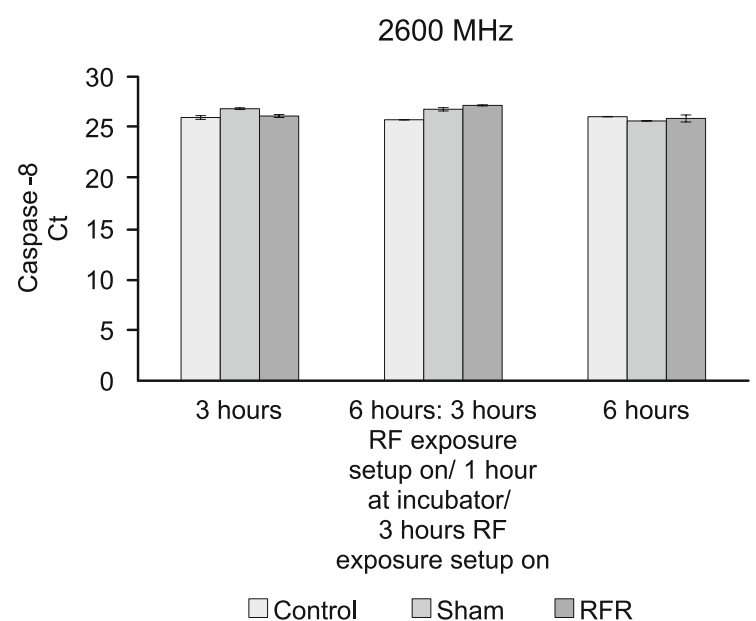

Fig. 11. The gene expression levels of CASP8 in HT-29 cells exposed to $2600 \mathrm{MHz}$ RF radiation for 3 hours continuous, 6 hours intermittent (HT-29 cells were exposed to RF radiation for 3 hours continuous/ 1 hour HT-29 cells were held at incubator / HT-29 cells were exposed to RF radiation for 3 hours continuous) and 6 hours continuous.

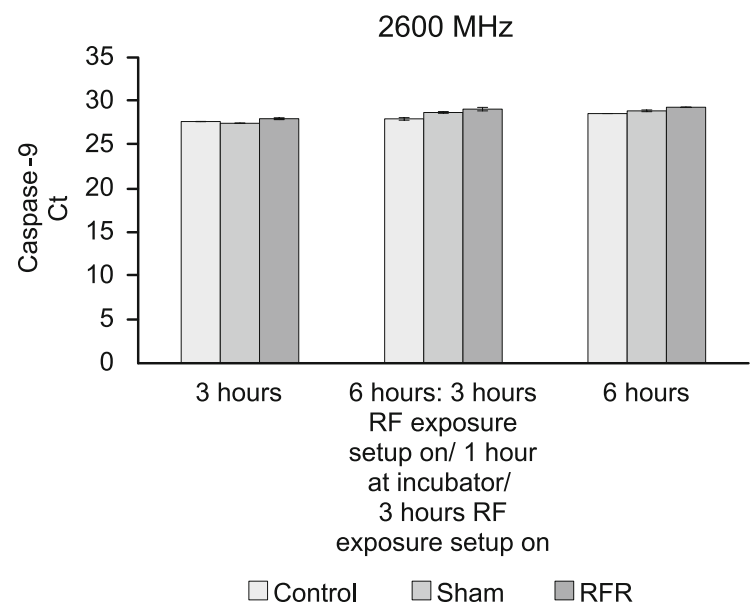

Fig. 12.The gene expression levels of CASP9 in HT-29 cells exposed to $2600 \mathrm{MHz}$ RF radiation for 3 hours continuous, 6 hours intermittent (HT-29 cells were exposed to RF radiation for 3 hours continuous/ 1 hour HT-29 cells were held at incubator / HT-29 cells were exposed to RF radiation for 3 hours continuous) and 6 hours continuous.

mitochondrial pathway (CASP9) and the endoplasmic reticulum stress-induced (CASP12) of cell death.

The homeostasis of colon epithelium, the balance between proliferation, senescence and death, can change under the influence of different internal and external factors resulting in the disruption of a signaling or the changes in the process of apoptosis. And mostly, these changes lead to the initiation and progression of an adenoma to carcinoma [colorectal cancer (CRC)] (Sancho et al, 2004). 


\section{$2600 \mathrm{MHz}$}

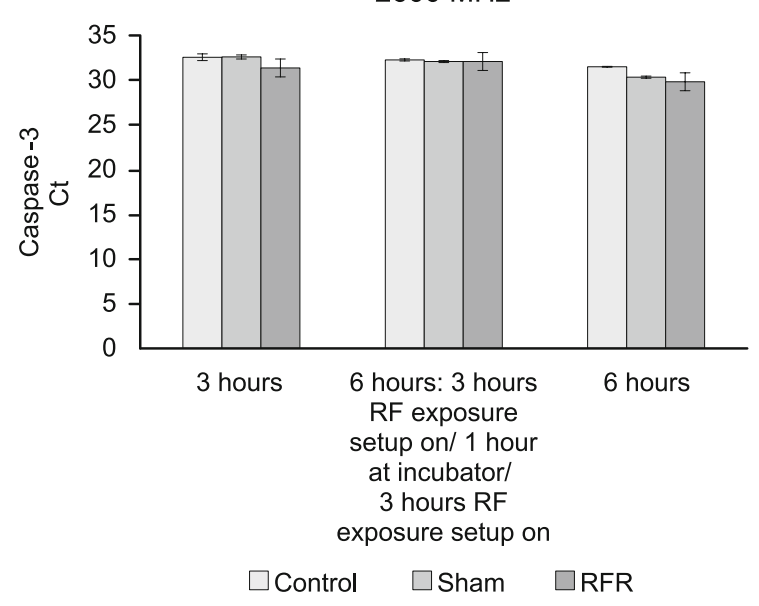

Fig. 13. The gene expression levels of CASP3 in HT-29 cells exposed to $2600 \mathrm{MHz}$ RF radiation for 3 hours continuous, 6 hours intermittent (HT-29 cells were exposed to RF radiation for 3 hours continuous/ 1 hour HT-29 cells were held at incubator / HT-29 cells were exposed to RF radiation for 3 hours continuous) and 6 hours continuous.

On defining the three distinct phases of carcinogenesis namely, the initiation, promotion, and progression stages, Radiofrequency (RF) Electromagnetic (EM) fields have been still investigated in detail as one of the environmental agents that have tumour promoting effect. Since quantum energies of RF radiation (RFR) are too low to be able to break the weakest intermolecular bonds, tumour promoting properties of these fields are mostly highlighted instead of their tumourigenic effect.

Radiofrequency/Microwave (MW) radiation interact with living systems in 3 main ways: i. Penetration into the tissue, ii. Their propagation into the living system, iii. The primary interaction of

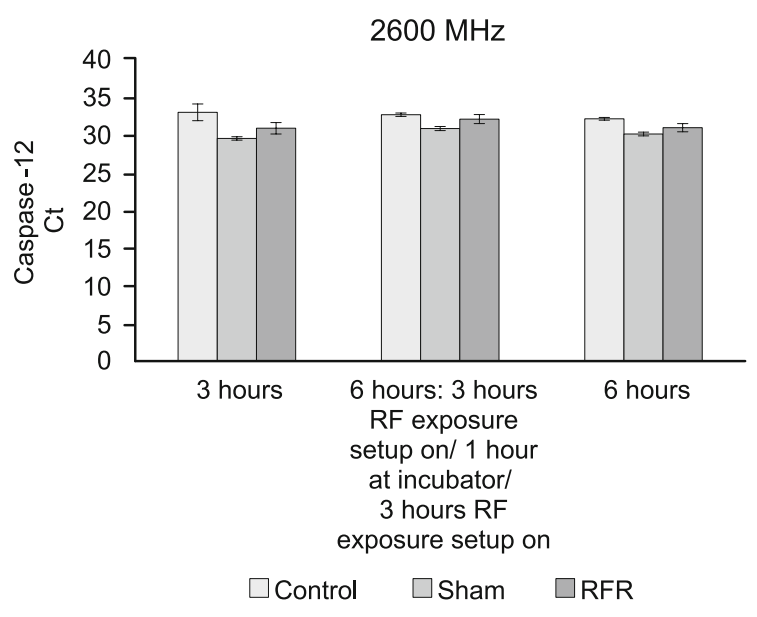

Fig. 14. The gene expression levels of CASP 12 in HT-29 cells exposed to $2600 \mathrm{MHz}$ RF radiation for 3 hours continuous, 6 hours intermittent (HT-29 cells were exposed to RF radiation for 3 hours continuous/ 1 hour HT-29 cells were held at incubator / HT-29 cells were exposed to RF radiation for 3 hours continuous) and 6 hours continuous.

the waves with tissue and the possible secondary effects arising from the primary interaction (Rachael, 2010). Furthermore, the resonance effect of RF/MW radiation may lead to genetic or epigenetic damage by the local overproduction of reactive intermediates or "free radicals" (Bioinitiative Report, 2008)

$\mathrm{RF} / \mathrm{MW}$ penetration into the living systems/ tissue that induces the over-production of free radicals or reactive intermediates [reactive oxygen/nitrogen species (ROS/RNS)]. Free radicals or ROS/ RNS are highly reactive intermediates and one of the internal initiating factors of the signaling mechanisms (Forman et al, 2014). In literature, the effect of radiofrequency radiation on reactive

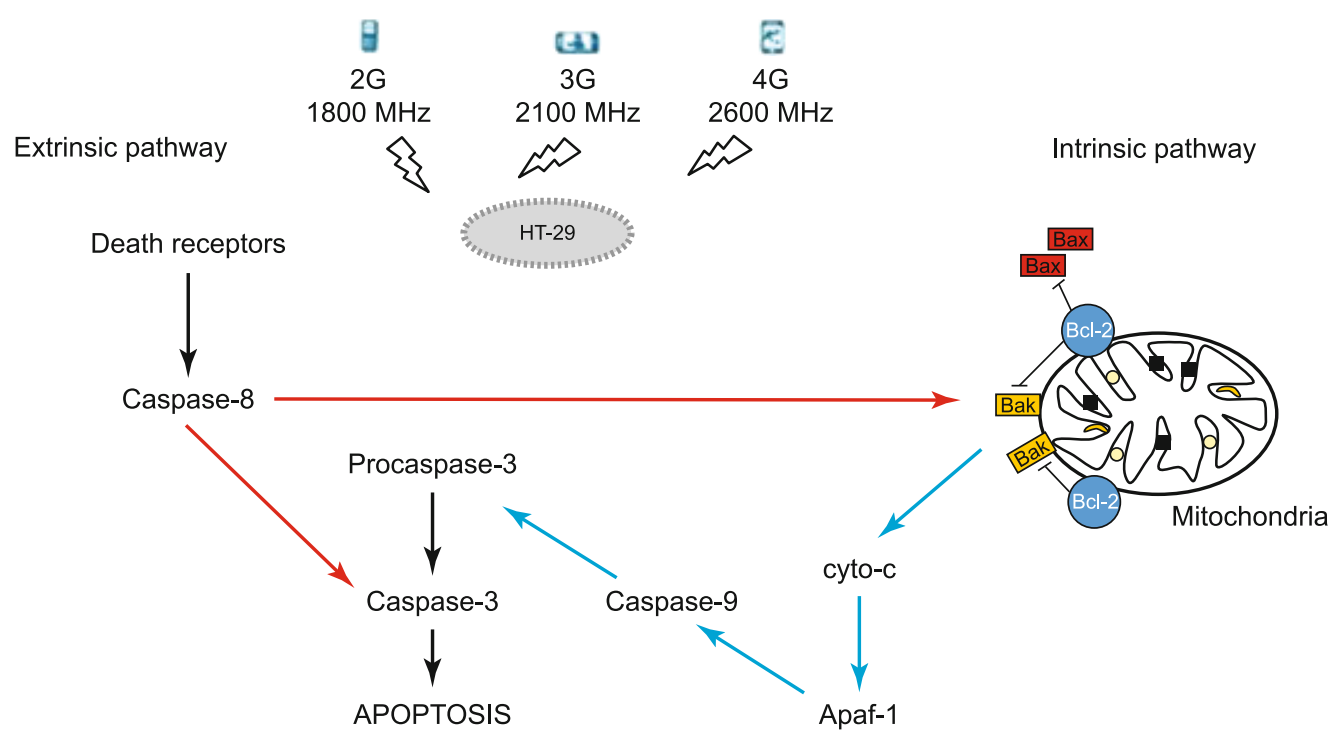

Fig. 15. Caspase-dependent apoptosis pathways induced by RF radiation. 
oxygen species has been shown as "an agent of ROS production" that induces negative cellular response in living organisms (Yakymenko et al, 2015, Dasdag et al, 2008, Kesari and Behari, 2009, 2012). Physiologically, reactive oxygen species are produced in response to various cellular functions, whereas antioxidant defense mechanism/system in mammals protect specifically to structural biomolecules (DNA, protein, lipid) against oxidative damage induced by radical intermediates (Güler et al, 2010, 2012, Tomruk et al, 2010, Ozgur et al, 2010, 2013, 2015, Kismali et al, 2012, Şahin et al, 2016, Xu et al 2010, Karaca et al, 2012) . ROS-related damage has contributed to the development of several diseases such as cancer, arteriosclerosis, arthritis, neurodegenerative disorders and others (Ames et al, 1993, Halliwell and Gutteridge, 1992). For example, in cancer cells, antioxidant activity should increase proportionally to ROS production for maintaining the cellular redox balance (Gorrini et al, 2013).

Cancer mechanisms can be evaluated in terms of both epigenetics and genetics. In the epigenetic process, combined effects of environmental factors do not directly affect and change genes, but genetic information can be modified by mutations in gene expressions which can lead to the development of cancer. In the literature, there are many scientific studies that show that RFR exposures at different frequencies can lead to genetic alterations or damage (single and double strand breaks, chromosomal aberrations, micronuclei, mutations, etc.) in different types of tissues (Lai and Singh, 1995, 1996, Nikolova et al, 2005,; Paulraj and Behari, 2006, Yao et al, 2008, Valbonesi et al, 2008, Schwarz et al, 2008, Sannino et al, 2009, Kumar et al, 2010, Garaj-Vrhovac et al, 2011, Güler et al, 2012, Kesari et al, 2014, Gandhi et al,; 2015; Deshmukh et al, 2016, Akdag et al, 2016, Sahin et al, 2016, Xing et al, 2016, Sun et al, 2017, Pandey et al, 2017).

In the present study, we found that the viable rates of HT-29 cells for $1800 \mathrm{MHz}$ and $2600 \mathrm{MHz}$ RF radiation exposure and for different exposure duration [3-h continuous, 6-h intermittent and 6-h continuous] were different from the findings of gene expression levels of CASP8, CASP9, CASP3 and CASP12. Although the viable cell rates decreased through the influence of prolonged exposure time, there were no differences in all gene expression levels we analyzed for all exposure duration. Actually, a reduction in the viable cell rate is characterized by both increased programmed cell death and also caspases activation (Smith et al, 2007, Oroz-Parra et al, 2016). Our results demonstrated that $1800 \mathrm{MHz}$ GSM-like RF signal and $2600 \mathrm{MHz}$ LTE Signal Repeater may induce cell death without leading to activation of the expression of apoptotic-related genes (CASP8, CASP9, CASP3 and CASP12). However, we observed the highest effect at 2100 $\mathrm{MHz}$ UMTS-like RF radiation exposure on both the viable cell rates and gene expression levels. Reduced viable cell rates with the activation of caspases can be observed properly in our HT-29 cells exposed to $2100 \mathrm{MHz}$ RFR. Among the RF frequencies we applied to HT-29 cells, the most decreases in viable cells were shown at $2100 \mathrm{MHz}$ RFR. In the present study, we also tried to evaluate the apoptosis pathways by caspases activation. Caspases are important initiators of apoptosis. Apoptosis is activated by caspases, which trigger cell death by cleaving specific proteins in the cytoplasm and nucleus. Caspases $-8,-9$, and -10 (initiator caspases) initiate the propagation of the apoptotic signals whereas caspases $-3,-6$, and -7 (effector caspases) execute the apoptotic program by cleaving numerous cellular proteins. In the present study, we found the gene expression level of initiator caspases (caspases-8 and caspases-9) significantly increased when 2100 $\mathrm{MHz}$ RF radiation was applied for 3 hours continuously and 6 hours intermittently. Generally, Caspase- 8 then activates downstream effector caspases such as caspase-3, resulting in apoptosis. And the intrinsic apoptotic pathway is characterized by the activation of the apoptotic function of mitochondria, [the release of cytochrome c, and activation of caspase-9]. Following the activation of caspase- 9 in the apoptosome the cleavage of caspase- 3 occurs. In our study, Caspase- 3 gene expression levels were, however, found to increase significantly only during 6 hours of intermittent exposure (Fig. 15)

Another pathway that triggers apoptosis is the endoplasmic reticulum stress dependent apoptotic pathway. (Nagakawa et al, 2000, Yoneda et al, 2001). An increased amount of intracellular free $\mathrm{Ca} 2+$ leads to the activation of calpain and the conversion of inactive pro-caspase-12 to active Caspase-12. Active Caspase-12 can mediate directly the activation of Caspase- 3 that has been activated by the inactive pro-caspase-9 passed through the cytoplasm without cytochrom c (Fan et al, 2005). According to our results, it can be said that $2100 \mathrm{MHz}$ RF radiation can activate both caspase- 8 - death receptor pathway initiator caspase and caspase- 9 - internal mitochondrial pathway initiator caspase- and that the initiator caspases can activate caspase-3 after 3 hours of exposure. Yet, the fact that there was no change in gene expression levels of caspase-12 according to its own negative control and sham groups indicated that caspase- 9 and caspase- 3 activation was not leading to apoptosis due to endoplasmic reticulum stress. Lu et al (2012) also confirm our results, in this study, the authors show that exposure to $900 \mathrm{MHz}$ GSM like RF radiation for different exposure duration $(1,2,3,4 \mathrm{~h})$ can activate and increase caspase-3 level in human blood mononuclear cells (Lu et al, 2012). Zhao et al (2007) determine that exposure to $1900 \mathrm{MHz}$ GSM modulated RF radiation for 2 hours upregulated Caspase-2, Caspase- 6 and Asc (Zhao et al, 2007). Palumba et al (2008) found that a slight but statistically significant increase in caspase 3 activity occurs in Jurkat cells exposed to $900 \mathrm{MHz}$ GSM signals for 1 hour (Palumbo et al, 2008). Zuo et al (2014) revealed that microwave radiation could induce neural cell apoptosis via the classical mitochondriadependent caspase-3 pathway. According to their study exposure to $2.856 \mathrm{GHz} \mathrm{MW}$ radiation for $5 \mathrm{~min}$ and $15 \mathrm{~min}$, apoptosis indicators (chromatin condensation, apoptotic body formation, the mitochondria membrane potential decreased, DNA fragmentation increased, the ratio of $\mathrm{Bax} / \mathrm{Bcl}-2$, expression of cytochrome c, cleaved caspase- 3 and PARP all increased) increased in neural cells (Zuo et al, 2014).

In summary, apoptosis plays an active role in many pathological and physiological actions. Therefore, interfering in the apoptotic process and re-arranging it can bring new methods of treatment into discussion. Our study may be beneficial for other experiments and also further investigations on in vitro mechanism 
of RF radiation at different frequencies. Further studies are necessary to determine the precise mechanism of caspase-dependent apoptosis induced by radiofrequency radiation.

\section{References}

1. Ahlbom A, Feychting M. Electromagnetic radiation. British Medical Bulletin 2003; 68: 157-165.

2. Akdag MZ, Dasdag S, Canturk F, Karabulut D, Caner Y, Adalier N. Does prolonged radiofrequency radiation emitted from Wi-Fi devices induce DNA damage in various tissues of rats? J Chem Neuroanat 2016; 75 (Pt B): 116-122.

3. Alberts B, Johnson A, Lewis J, Raff M, Roberts K, Walter P. Molecular biology of the cell. New York: 1994, Garland Sciences.

4. Ames NB, Shigenaga MK, Hagen TM. Oxidants, antioxidants, and the degenerative disease of aging. Proc Natl Acad Sci USA 1993; 90 : 7915-7922.

5. Belyaev I. Non-thermal biological effects of microwaves. Microwave Rev 2005a; 11, 13-29.

6. Belyaev I. Nonthermal biological effects of microwaves: Current knowledge, further perspective, and urgent needs. Electromagn Biol Med 2005b; 24: 375-403.

7. BioInitiative Working Group. In: Sage C, Carpenter DO (Eds). BioInitiative report: a rationale for a biologically-based public exposure standard for electromagnetic fields (ELF and RF); 2007. 2008. http: //www. bioinitiative.org

8. Dasdag S, Bilgin HM, Akdag MZ et al. Effect of long term mobile phone exposure on oxidative-antioxidative processes and nitric oxide in rats. Biotech Biotechn Equip 2008; 22: 992-997.

9. Deshmukh PS, Megha K, Nasare N, Banerjee BD, Ahmed RS, Abegaonkar MP, Tripathi AK, Mediratta PK. Effect of Low Level Subchronic Microwave Radiation on Rat Brain. Biomed Environ Sci 2016; 29 (12): 858-867.

10. Fan TJ, Han LH, Cong RS, Liang J. Caspase Family Proteases and Apoptosis. Acta Biochim Biophys Sinica 2005; 37 (11): 719-727.

11. Forman HJ, Ursini F, Maiorino M. An overview of mechanisms of redox signaling. J Mol Cell Cardiol 2014; 73: 2-9.

12. French PW, Penny R, Laurence JA, McKenzie DR. Mobile phones, heat shock protein and cancer. Differentiation 2001; 67: 93-97.

13. Gandh, G, Kaur G, Nisar UA. Cross-sectional case control study on genetic damage in individuals residing in the vicinity of a mobile phone base station Electromagn Biol Med 2015; 34 (4): 344-354.

14. Garaj-Vrhovac V, Gajski G, Pažanin S, Sarolic A, Domijan AM, Flajs D, Peraica M. Assessment of cytogenetic damage and oxidative stress in personnel occupationally exposed to the pulsed microwave radiation of marine radar equipment. Int J Hyg Environ Health 2001; 4: 59-65.

15. Gorrini C, Harris IS, Mak TW. Modulation of oxidative stress as an anticancer strategy. Nat Rev Drug Discov 2013; 12: 931-947.

16. Güler G, Tomruk A, Ozgur E, Sahin D, Sepici A, Altan N, Seyhan $\mathbf{N}$. The effect of radiofrequency radiation on DNA and lipid damage in female and male infant rabbits. Int J Radiat Biol 2012; 88 (4): 367-373.

17. Güler G, Tomruk A, Ozgur E, Seyhan N. The effect of radiofrequency radiation on DNA and lipid damage in non-pregnant and pregnant rabbits and their newborns. Gen Physiol of Biophys 2010; 29, 59-66.
18. Halliwell B, Gutteridge JMC, Cross CE. Free-radicals, antioxidants, and human-disease - Where are we now. J Lab Clin Med 1992; 119: 598-620.

19. Karaca E, Durmaz B, Aktug H, Yildiz T, Guducu C, Irgi M, Koksal MG, Ozkinay F, Gunduz C, Cogulu $O$. The genotoxic effect of radiofrequency waves on mouse brain. J Neurooncol 2012; 106: 53-58.

20. Kesari KK, Meena R, Nirala J, Kumar J, Verma HN. Effect of 3G cell phone exposure with computer controlled 2-D stepper motor on nonthermal activation of the hsp27/p38MAPK stress pathway in rat brain. Cell Biochem Biophys 2014; 68 (2): 347-358.

21. Kesari KK, Behari J. Fifty microwave exposure effect of radiations on rat brain. Appl Biochem Biotechnol 2009; 158: 126-139.

22. Kesari KK, Kumar S, Behari J. Evidence for mobile phone radiation exposure effects on reproductive pattern of male rats: Role of ROS. Electromag Biol Med 2012; 31: 213-222.

23. Kısmalı G, Ozgur E, Guler G, Akcay A, Sel T, Seyhan N. The influence of $1800 \mathrm{MHz}$ GSM-like signals on blood chemistry and oxidative stress in non-pregnant and pregnant rabbits. Internat J Radiat Biol 2012; 88 (5): 414-419.

24. Kumar S, Kesari KK, Behari J. Evaluation of genotoxic effects in male Wistar rats following microwave exposure. Indian J Exp Biol 2010; 48: $586-592$.

25. Lai H, Singh NP. Acute low-intensity microwave exposure increases DNA single-strand breaks in rat brain cells. Bioelectromagnetics 1995; 16 (3): 207-210.

26. Lai H, Singh NP. Single- and double-strand DNA breaks in rat brain cells after acute exposure to radiofrequency electromagnetic radiation. Int J Radiat Biol 1996; 69 (4): 513-521.

27. Livak KJ, Schmittgen TD. Analysis of relative gene expression data using real-time quantitative PCR and the 2-CT method. Methods 2008; 25 (4): 402-408.

28. Nakagawa T, Zhu H, Morishima N, Li E, Xu J, Yankner BA, Yuan J. Caspase-12 mediates endoplasmic-reticulum-specific apoptosis and cytotoxicity by amyloid. Nature 2000; 403: 98-103.

29. Nikolova T, Czyz J, Rolletschek A, Blyszczuk P, Fuchs J, Jovtchev G, Schuderer J, Kuster N, Wobus AM. Electromagnetic fields affect transcript levels of apoptosis-related genes in embryonic stem cell-derived neural progenitor cells. FASEB J 2005; 19: 1686-1688.

30. Non-Ionizing Radiation, Part 2: Radiofrequency Electromagnetic Fields. IARC Monographs on the Evaluation of Carcinogenic Risks to Humans, No. 102. IARC Working Group on the Evaluation of Carcinogenic Risk to Humans. Lyon (FR): International Agency for Research on Cancer; 2013.

31. Oroz-Parra I, Navarro M, Cervantes-Luevano KE, Álvarez-Delgado C, Salvesen G, Sanchez-Campos LN, Licea-Navarro AF. Apoptosis Activation in Human Lung Cancer Cell Lines by a Novel Synthetic Peptide Derived from Conus californicus Venom, Toxin 2016; 8 (2): 38. doi: $10.3390 /$ toxins 8020038

32. Ozgur E, Güler G, Seyhan N. Mobile phone radiation- induced free radical damage in the liver is inhibited by the antioxidants n-acetyl cysteine and epigallocatechin-gallate. Internat J Radiat Biol 201; 86 (11): 935-945.

33. Ozgur E, Kısmalı G, Güler G, Akçay A, Özkurt G, Sel T, Seyhan N. Effects of prenatal and postnatal exposure to GSM-like radiofrequency on blood chemistry and oxidative stress in infant rabbits an experimental study. Cell Biochem Biophys 2013; 67 (2): 743-751. 
34. Ozgur E, Sahin D, Tomruk A, Güler G, Sepici-Dinçel A, Altan N, Seyhan N. The effects of N-acetylcysteine and epigallocatechin-3-gallate on liver tissues protein oxidation and antioxidant enzyme levels after the exposure to radiofrequency radiation. Internat J Radiat Biol 2015; 91 (2): 187-193.

35. Palumbo R, Brescia F, Capasso D et al. Exposure to $900 \mathrm{MHz}$ radiofrequency radiation induces caspase 3 activation in proliferating human lymphocytes. Radiat Res 2008; 170 (3): 327-334.

36. Panagopoulos DJ. Electromagnetic Interaction between Environmental Fields and Living Systems Determines Health and Well-Being. In Electromagnetic Fields: Principles, Engineering Applications and Biophysical Effects. Editors: Myung-Hee Kwang and Sang-Ook Yoon, pp. 87-130, 2013, Series: Physics Research and Technology.

37. Pandey N, Giri S, Das S, Upadhaya P. Radiofrequency radiation (900 $\mathrm{MHz}$-induced DNA damage and cell cycle arrest in testicular germ cells in swiss albino mice. Toxicol Ind Health 2017; 33 (4): 373-384.

38. Paulraj R, Behari J. Single strand DNA breaks in rat brain cells exposed to microwave radiation. Mutat Res 2006; 11 (1-2): 76-80.

39. Rachael UM. Somatic and genetic effects of low SAR $2.45 \mathrm{GHz}$ microwave radiation on wistar rats. Ota: School of Post Graduate Studies of Covenant University, 2010. p. 1.

40. Redlarski G, Lewczuk B, Żak A, Koncicki A, Krawczuk M, Piechocki J, Jakubiuk K, Tojza P, Jaworski J, Ambroziak D, Skarbek $\mathbf{L}$, Gradolewski $\mathbf{D}$. The Influence of Electromagnetic Pollution on Living Organisms: Historical Trends and Forecasting Changes. BioMed Res Internat 2015; 18 pp.

41. Şahin D, Özgür E, Güler G, Tomruk A, Unlu I, Sepici-Dinçel A, Seyhan N. The $2100 \mathrm{MHz}$ radiofrequency radiation of a 3G-mobile phone and the DNA oxidative damage in brain. J Chem Neuroanat 2016; 75 (Part B): 94-98.

42. Sancho E, Batlle E, Clevers H. Signaling pathways in intestinal development and cancer. Ann Rev Cell Dev Biol 2004; 20: 695-723.

43. Sannino A, Di Costanzo G, Brescia F, Sarti M, Zeni O, Juutilainen J, Scarfî MR. Human fibroblasts and $900 \mathrm{MHz}$ radiofrequency radiation: evaluation of DNA damage after exposure and co-exposure to 3-chloro4-(dichloromethyl)-5-hydroxy-2(5h)-furanone (MX). Radiat Res 2009; 171 (6): 743-751.

44. Schwarz C, Kratochvil E, Pilger A, Kuster N, Adlkofer F, Rüdiger HW. Radiofrequency electromagnetic fields (UMTS, 1,950 MHz) induce genotoxic effects in vitro in human fibroblasts but not in lymphocytes. Int Arch Occup Environ Health 2008; 81 (6): 755-767.
45. Smith JG, Joseph HR, Green T, Field JA, Wooters M, Kaufhold RM, Antonello J, Caulfield MJ. Establishing acceptance criteria for cellmediated-immunity assays using frozen peripheral blood mononuclear cells stored under optimal and suboptimal conditions. Clin Vaccine Immunol 2007; 14: 527-537.

46. Sun Y, Zong L, Gao Z, Zhu S, Tong J, Cao Y. Mitochondrial DNA damage and oxidative damage in HL-60 cells exposed to $900 \mathrm{MHz}$ radiofrequency fields. Mutat Res 2017; 797-799.

47. The WHO/International Agency For Research on Cancer (IARC) press release No 208. "IARC classifies radiofrequency electromagnetic fields as possibly carcinogenic to humans", 31 may 2011.

48. Tomatır AG. Apoptoz: Programlı hücre ölümü. Türk Klin J Med Sci 2003; 23 (6): 499

49. Tomruk A, Güler G, Sepici Dinçel A. The influence of $1800 \mathrm{MHz}$ GSM-like signals on hepatic oxidative DNA and lipid damage in nonpregnant, pregnant and newly born rabbits. Cell Biochem Biophys 2010; 56: $39-47$.

50. Xing F, Zhan Q, He Y, Cui J, He S, Wang G. 1800 MHz Microwave Induces p53 and p53-Mediated Caspase-3 Activation Leading to Cell Apoptosis in Vitro. PLoS One 2016; 30 (9): e0163935.

51. Xu S, Zhou Z, Zhang L, Yu Z, Zhang W, Wang Y, Wang X, Li M, Chen Y, Chen $\mathrm{C}$ et al. Exposure to $1800 \mathrm{MHz}$ radiofrequency radiation induces oxidative damage to mitochondrial DNA in primary cultured neurons. Brain Res 201; 1311: 189-196.

52. Yakymenko, I, Sidorik, E, Kyrylenko, S, Chekhun, V. Long-term exposure to microwave radiation provokes cancer growth: evidences from radars and mobile communication systems. Exp Oncol 2011; 33 (2): 62-70.

53. Yao K, Wu W, Wang K, Shuang N, PanPan Y, Yibo Y, Juan Y, Lixia S. Electromagnetic noise inhibits radiofrequency radiation-induced DNA damage and reactive oxygen species increase in human lens epithelial cells. Mol Vis 2008; 14: 964-969.

54. Yoneda T, Imaizumi K, Oono K, Yui D, Gomi F, Katayama T, Tohyama M. Activation of Caspase-12, an Endoplasmic Reticulum (ER) Resident Caspase, through Tumor Necrosis Factor Receptor-associated Factor2-dependent Mechanism in Response to the ER Stress. J Biol Chem 2001; 276 (17): 13935-13940.

55. Zhao L, Peng RY, Gao YB, Wang SM, Ma JJ, Wang LF et al. Screening for differentially expressed genes in rats' hippocampus after microwave radiation. Chin J Publ Health 2007; 23: 1153-1155.

56. Zuo HY, Lin T, Wang DW, Peng RY, Wang SM, Gao YB et al. Neural cell apoptosis induced by microwave exposure through mitochondriadependent caspase-3 pathway. Int J Med Sci 2014; 11: 426-435.

Received December 1, 2018. Accepted January 21, 2019. 